\title{
IMPLEMENTASI PENERBITAN SURAT KETERANGAN BEBAS (SKB) PAJAK PENGHASILAN (PPH) PENGALIHAN HAK ATAS TANAH DAN/ATAU BANGUNAN ATAS WARISAN DITINJAU DARI ASAS KEMUDAHAN ADMINISTRASI (STUDI KASUS KANTOR PELAYANAN PAJAK KOTA YOGYAKARTA)
}

\author{
Khoulud Beby Bestiani \\ Universitas Gadjah Mada, Indonesia, khouludbeby@gmail.com
}

\begin{abstract}
This study aims to analyze the implementation of the issuance of SKB PPh on the transfer of rights to land and/or buildings on inheritance at the Yogyakarta City Pratama Tax Service Office in terms of the principle of administrative convenience. This research is a type of empirical normative legal research that combines primary data and secondary data, primary data is data obtained in the field and secondary data is data obtained through library research. The data obtained is then analyzed qualitatively. The results obtained are, first, tax collection is said to be efficient if the cost of taxation/administrative costs is low, but in practice the cost of taxation/administrative costs borne by the heirs is high. Second, the principle of Convenience of Payment requires that tax collection must pay attention to the comfortable condition of the taxpayer, but the length of the process of issuing the SKB actually creates inconvenience that causes losses to the heirs, namely that the sale and purchase of inherited land cannot be carried out immediately and the heirs lose the opportunity to develop his efforts. Third, with the length of time for the issuance of the SKB PPh, it is not in accordance with the simple principle which requires that taxation procedures must be fast, smooth and precise.
\end{abstract}

Keyword: SKB PPh, Inheritance, Ease of Administration

\begin{abstract}
Abstrak
Penelitian ini bertujuan untuk menganalisis implementasi penerbitan SKB PPh pengalihan hak atas tanah dan/bangunan atas warisan di Kantor Pelayanan Pajak Pratama Kota Yogyakarta di tinjau dari asas kemudahan administrasi. Penelitian ini merupakan jenis penelitian hukum normatif empiris yang menggabungkan antara data primer dan data sekunder,data primer yaitu data yang didapat di lapangan dan data sekunder yaitu data yang didapat melalui penelitian kepustakaan.Data yang diperoleh selanjutnya dianalisis secara kualitatif. Hasil penelitian yang didapat yakni, pertama, pemungutan pajak dikatakan efisien jika cost of taxation/administrative costs atau beban administratifnya rendah, namun dalam prakteknya cost of taxation/administrative costs yang ditanggung oleh ahli waris tinggi. Kedua, asas Convenience of Payment menghendaki bahwa pemungutan pajak harus memperhatikan kondisi wajib pajak yang nyaman, namun lamanya proses penerbitan SKB tersebut justru memberikan ketidaknyamanan yang menimbulkan kerugian bagi ahli waris yaitu tidak dapat dilakukannya jual beli tanah warisan dengan segera dan ahli waris kehilangan kesempatan untuk mengembangkan usahanya. Ketiga, dengan lamanya jangka waktu penerbitan SKB PPh tersebut maka tidak sesuai dengan asas sederhana yang mengharuskan bahwa prosedur perpajakan harus cepat, lancar dan tepat.

Kata kunci: $\mathrm{SKB} \quad \mathrm{PPh}, \quad$ Warisan, Kemudahan Administrasi
\end{abstract}




\section{A. Pendahuluan}

Tanah merupakan salah satu sumber kehidupan yang sangat penting bagi manusia, baik dalam fungsinya sebagai sarana untuk mencari penghidupan, maupun sebagai tempat untuk bermukim dengan didirikannya perumahan sebagai tempat tinggal, atas tanah tersebut dapat dilekati hak diatasnya. Hak atas tanah adalah hak yang memberi wewenang kepada yang mempunyai hak untuk menggunakan atau mengambil manfaat dari tanah yang dihakinya. ${ }^{1}$ Dalam UUPA dinyatakan bahwa hak atas tanah dapat beralih dan dialihkan dari pemegang haknya kepada pihak lain. ${ }^{2}$ Salah satu bentuk peralihan hak atas tanah dengan cara beralih yaitu melalui pewarisan. Pewarisan hak atas tanah ini terjadi karena hukum, artinya dengan meninggalnya pemegang hak, maka ahli warisnya memperoleh hak atas tanah tersebut.

Ketentuan tentang pendaftaran pengalihan hak atas tanah dan/bangunan

${ }^{1}$ Sudikno mertokusumo,1988, Hukum dan Politik Agraria, Karunika Univeristas Terbuka, Jakarta, hlm.445

${ }^{2}$ Pasal 20 ayat (2) Undang-Undang Nomor 5 Tahun 1960 tentang Peraturan Dasar Pokok-Pokok Agraria mewajibkan atau mensyaratkan pajak-pajak atas tanah tersebut harus dibayarkan seperti BPHTB (Bea Perolehan Hak atas Tanah dan Bangunan) dan PPh (Pajak Penghasilan). Terkait dengan ahli waris yang akan melakukan pengalihan hak atas tanah dan/bangunan karena pewarisan, ahli waris disyaratkan untuk membayar pajak BPHTB (Bea Perolehan Hak atas Tanah dan Bangunan) dikarenakan adanya suatu peristiwa yaitu ahli waris mendapat tanah dan bangunan tersebut melalui pewarisan, dan di sebutkan dalam Undang-Undang bahwasanya pemindahan hak karena warisan termasuk objek pajak BPHTB. ${ }^{3}$

Dalam hal pemungutan $\mathrm{PPh}$ atas pengalihan hak atas tanah dan/bangunan karena warisan, ahli waris tidak diwajibkan untuk membayarkannya. Hal tersebut sesuai dengan ketentuan Pasal 4 ayat (3) Undangundang Nomor 36 tahun 2008 tentang Pajak Penghasilan (UU PPh) dan Pasal 6 huruf d Peraturan Pemerintah No. 34 Tahun 2016 tentang $\mathrm{PPh}$ atas Penghasilan dari Pengalihan Hak atas Tanah dan/atau

\footnotetext{
${ }^{3}$ Pasal 2 Undang-Undang Nomor 20 tahun 2000 tentang Bea Perolehan Hak atas Tanah dan/Bangunan
} 
Bangunan, dan Perjanjian Pengikatan Jual Beli atas Tanah dan/atau Bangunan yang menyebutkan bahwa dikecualikan dari kewajiban pembayaran atau pemungutan Pajak Penghasilan atas penghasilan dari pengalihan harta berupa tanah dan/atau bangunan karena warisan, sehingga warisan termasuk penghasilan yang dikecualikan sebagai objek pajak.

Agar ahli waris dikecualikan dari pemungutan biaya $\mathrm{PPh}$ atas penghasilan hak atas tanah dan/bangunan, maka berdasarkan Pasal 3 ayat (1) huruf a Peraturan Direktorat Jenderal Pajak Nomor 30/PJ/2009 tentang Tata Cara Pemberian Pengecualian dari Kewajiban Pembayaran atau Pemungutan Pajak Penghasilan atas Penghasilan dari Pengalihan Hak atas Tanah dan/atau Bangunan menyebutkan bahwa di dalam pengalihan hak atas tanah dan/bangunan karena warisan mensyaratkan bahwa harus disertai dengan adannya SKB (Surat Keterangan Bebas).

Berkaitan dengan Penerbitan SKB PPh warisan, dalam Pasal 5 Peraturan Direktorat Jenderal Pajak Nomor 30/PJ/2009 disebutkan bahwasanya atas permohonan SKB PPh atas penghasilan dari pengalihan hak atas tanah dan/bangunan, Kepala Kantor Pelayanan Pajak (KPP) harus memberikan keputusan dalam jangka waktu paling lama
3 (tiga) hari kerja sejak tanggal surat permohonan SKB tersebut diterima secara lengkap, Apabila dalam jangka waktu tersebut Kepala KPP tidak memberikan keputusan, maka permohonan SKB tersebut dianggap dikabulkan dan Kepala KPP harus menerbitkan SKB PPh tersebut paling lama 2 (dua) hari.

Permasalahan ditemukan apabila keputusan permohonan SKB PPh pengalihan hak atas tanah dan/bangunan karena warisan yang diajukan oleh ahli waris diterbitkan melebihi jangka waktu yang telah ditentukan oleh Peraturan Direktorat Jenderal pajak. Menurut Bimo Sanjaya selaku Notaris dan/atau PPAT Kota Yogyakarta menyebutkan bahwa keputusan terhadap pengajuan permohonan SKB $\mathrm{PPh}$ atas pengalihan hak atas tanah dan/bangunan karena warisan yang diajukan oleh ahli waris pada prakteknya membutuhkan waktu sekitar 14 (empat belas)-30 (tiga puluh hari) atau lebih sejak SKB tersebut diajukan. Dengan lamanya keputusan atas permohonan SKB PPh tersebut maka dapat berpengaruh terhadap proses pendaftaran pengalihan hak atas tanah dan/bangunan atas warisan yang akan dilakukan oleh ahli waris. $^{4}$

4 Hasil wawancara dengan Bimo Seno Sanjaya, S.H, Notaris dan PPAT di Kota Yogyakarta, pada tanggal 04 Mei 2020. 
Hal tersebut menarik perhatian mengenai isu tentang asas kemudahan administrasi dalam pengalihan hak atas tanah dan/bangunan karena warisan. Pada asas kemudahan administrasi ini menginginkan bahwasanya peraturan pajak tidak memberatkan wajib pajak dalam melaksanakan kewajiban perpajakan. Untuk menilai kebijakan peraturan pajak tersebut telah menerapkan asas kemudahan administrasi dapat dinilai melalui empat indikator yang terdiri dari asas certainty (kepastian hukum), efficiency (efisien), convenience of payment (memperhatikan kondisi wajib Pajak), dan simplicity (sederhana). ${ }^{5}$

Berdasarkan uraian latar belakang tersebut di atas selanjutnya penulis tertarik untuk melakukan penelitian dengan judul "Implementasi Penerbitan Surat Keterangan Bebas (SKB) Pajak Penghasilan (PPh) Pengalihan Hak Atas Tanah Dan/Atau Bangunan atas Warisan Ditinjau Dari Asas Kemudahan Administrasi (Studi Kasus Kantor Pelayanan pajak Kota Yogyakarta).”

\footnotetext{
5 Rosdiana,H \& Irianto,E.S, 2012, Pengantar Ilmu Pajak, PT Raja Grafindo, Jakarta, hlm. 168
}

\section{Rumusan Masalah}

Sesuai dengan latar belakang masalah tersebut di atas, maka rumusan masalah pada penelitian ini adalah sebagai berikut:

Bagaimana Implementasi Penerbitan Surat Keterangan Bebas (SKB) Pajak Penghasilan (PPh) Pengalihan Hak Atas Tanah Dan/Atau Bangunan atas Warisan Ditinjau Dari Asas Kemudahan Administrasi (Studi Kasus: Kantor Pelayanan Pajak Kota Yogyakarta)?

\section{Metode Penelitian}

Penelitian ini merupakan jenis penelitian yang bersifat normatif empiris. Penelitian hukum normatif empiris merupakan penggabungan penelitian hukum normatif dan penelitian hukum empiris dengan menekankan pada penelitian berdasarkan data dan fakta hukum yang didapat langsung dari lapangan. ${ }^{6}$ Penelitian hukum ini bersifat deskriptif (Descriptive research), yakni penelitian yang bertujuan untuk menata dan mengklarifikasi gejalagejala yang akan digambarkan oleh peneliti dengan sebanyak mungkin diusahakan mencapai kesempurnaan atas dasar bangunan penelitian. ${ }^{7}$ Metode analisis data penelitian dilakukan secara kualitatif, yaitu

\footnotetext{
6 Bambang Sunggono,2006, Metodologi Penelitian, Raja Grafindo, Jakarta, hlm.72

${ }^{7}$ Maria SW Sumardjono,2014, Metodologi Penelitian Hukum, Universitas Gadjah Mada, Yogyakarta, hlm.33
} 
data yang telah dikumpulkan baik dari penelitian lapangan maupun penelitian kepustakaan dianalisis secara kualitatif.

\section{B. Hasil Penelitian dan Pembahasan}

\section{Perlakuan Fiskus Terhadap Harta Warisan}

Dalam proses pendaftaran pengalihan hak atas tanah dan/bangunan karena warisan agar ahli waris dapat dikecualikan dari pemungutan dan pembayaran $\mathrm{PPh}$ warisan, Kantor Pertanahan Kota Yogyakarta mewajibkan ahli waris untuk mengajukan surat permohonan SKB PPh pengalihan hak atas tanah dan/bangunan karena warisan terlebih dahulu ke Kantor Pelayanan Pajak Pratama Kota Yogyakarta. Menurut Bimo Sanjaya selaku Notaris di Kota Yogyakarta, menyatakan bahwa Kota Yogyakarta adalah daerah yang memiliki keistimewaan karena untuk wilayah Provinsi Daerah Istimewa Yogyakarta, hanya Kantor Pertanahan Kota Yogyakarta yang mewajibkan ahli waris untuk mengajukan permohonan SKB PPh terlebih dahulu ke Kantor Pelayanan Pajak Pratama Kota Yogyakarta, sedangkan untuk kabupaten Bantul, Sleman, Gunung kidul dan Kulonprogo tidak mewajibkan ahli waris untuk mengajukan SKB PPh dalam pengalihan hak atas tanah dan/bangunan apabila ingin dikecualikan dari pembayaran dan pemungutan $\mathrm{PPh}$ atas warisan. ${ }^{8}$

Menurut Retno selaku Kepala Seksi Pemeliharaan Data Hak atas Tanah dan Pembinaan PPAT pada Kantor Pertanahan Kota Yogyakarta, hal tersebut dilaksanakan berdasarkan Pasal 2 dan Pasal 3 Peraturan direktur Jenderal Pajak Nomor 30/PJ/2009 tentang Tata Cara Pemberian pengecualian dari Kewajiban Pembayaran atau Pemungutan Pajak Penghasilan Atas penghasilan dari pengalihan hak Atas tanah dan/atau bangunan yang di dalam Pasal 2 SE Direktorat jenderal pajak tersebut menyebutkan bahwa dikecualikan dari kewajiban pembayaran atau pemungutan pajak Penghasilan atas penghasilan hak atas tanah dan/atau bangunan salah satunya adalah pengalihan hak atas tanah dan/bangunan karena warisan. Lebih lanjut dijelaskan dalam Pasal 3 menyebutkan bahwa pengecualian dari kewajiban pembayaran atau pemungutan pajak penghasilan karena warisan diberikan dengan penerbitan surat keterangan bebas pajak penghasilan atas penghasilan dari

\footnotetext{
8 Hasil wawancara dengan Bimo Seno Sanjaya, S.H, Notaris dan PPAT di Kota Yogyakarta, pada tanggal 04 Mei 2020.
} 
pengalihan hak atas tanah dan/atau bangunan. ${ }^{9}$

Retno menjelaskan bahwa Kantor Pertanahan Kota Yogyakarta hanya sebagai pelaksana aturan yang ada, untuk penerbitan SKB PPh tersebut lebih lanjut dapat ditanyakan kepada Kantor Pelayanan Pajak Kota Yogyakarta, karena yang berwenang untuk menolak dan mengabulkan surat keterangan bebas $\mathrm{PPh}$ adalah KPP Kota Yogyakarta. Kemudian, Retno juga memaparkan bahwa kewajiban ahli waris untuk mengajukan permohonan SKB PPh atas warisan tersebut berlaku bagi Pewaris semasa hidup memiliki NPWP dan Pewaris yang tidak memiliki NPWP. ${ }^{10}$ Maya menjelaskan, bahwa di dalam Surat Edaran Direktur Jenderal Pajak Nomor 20/PJ/2015 memuat aturan yang berbunyi "mengingat pewaris telah meninggal dunia maka pengajuan permohonan SKB $\mathrm{PPh}$ atas penghasilan dari pengalihan hak atas tanah dan/atau bangunan diajukan oleh ahli waris ke Kantor Pelayanan Pajak (KPP) tempat pewaris sebagai pihak yang mengalihkan hak atas tanah dan/bangunan, terdaftar atau

\footnotetext{
${ }^{9}$ Hasil wawancara dengan Retno Kepala Seksi Pemeliharaan Data Hak atas Tanah dan Pembinaan PPAT pada Kantor Pertanahan Kota Yogyakarta, tanggal 03 Juni 2020

10 Hasil wawancara dengan Retno Kepala Seksi Pemeliharaan Data Hak atas Tanah dan Pembinaan PPAT pada Kantor Pertanahan Kota Yogyakarta, tanggal 03 Juni 2020
}

bertempat tinggal". Dari aturan tersebut maka dapat dimaknai secara eksplisit bahwasannya apabila Pewaris semasa hidup memiliki NPWP maka permohonan SKB diajukan ke KPP dimana pewaris terdaftar, sedangkan bagi Pewaris yang tidak memiliki NPWP semasa hidup maka permohonan SKB diajukan ke KPP tempat dimana Pewaris bertempat tinggal. ${ }^{11}$

Kepemilikan NPWP Pewaris berpengaruh terhadap penerbitan SKB $\mathrm{PPh}$ atas warisan apabila wajib pajak tersebut meninggal, hal tersebut dikarenakan sistem perpajakan yang dianut oleh Indonesia adalah Self Assesment System, artinya suatu sistem pemungutan pajak yang memberi kepercayaan penuh kepada wajib pajak untuk menghitung, memperhitungkan dan membayar sendiri pajak yang terutang sesuai dengan peraturan perundang-undangan perpajakan, sehingga penentuan besarnya pajak yang terutang tergantung pada wajib pajak sendiri, sedangkan fiskus atau petugas pajak bertugas sebagai pengendalian, pembinaan, penelitian, pengawasan, dan penetapan sanksi $^{12}$ Selanjutnya, sebagai sarana utama yang diperlukan oleh wajib pajak untuk menghitung, membayar,

${ }^{11}$ Hasil wawanvara dengan Maya selaku account Representative Kantor Pelayanan Pajak Pratama Kota Yogyakarta, pada tanggal 29 Juli 2020

\footnotetext{
${ }^{12}$ Djamaludin Gede,Loc.Cit.,
} 
melaporkan serta mempertanggungjawabkan jumlah pajak yang terutang maka wajib pajak yang telah memiliki NPWP tersebut wajib mengisi formulir surat pemberitahuan (SPT).

Berdasarkan

PER-30/PJ/2009

menyebutkan bahwa syarat suatu tanah dan/atau bangunan dapat dikatakan sebagai warisan yang bukan merupakan objek pajak sehingga dapat diterbitkan SKB (Surat keterangan Bebas) PPh adalah: ${ }^{13}$

1) Pewaris dan ahli waris harus ada hubungan keluarga sedarah dalam garis keturunan lurus satu derajat;

2) Harta bergerak maupun harta tidak bergerak yang diwariskan tersebut telah dilaporkan dalam Surat Pemberitahuan Tahunan (SPT) pewaris dan pajak terutang (jika ada) harus dilunasi terlebih dahulu.

Pengaturan lebih lanjut terkait SKB diatur dalam SE Direktur Jenderal Pajak nomor SE-20/PJ/2015 yang menyebutkan:

"SKB $\mathrm{PPh}$ atas penghasilan dari pengalihan hak atas tanah dan/atau bangunan hanya diberikan apabila tanah dan/atau bangunan yang menjadi objek pewarisan telah dilaporkan dalam SPT tahunan PPh Pewaris, kecuali pewaris memiliki penghasilan dibawah penghasilan kena pajak."

13 Hasil wawancara dengan Dr. $H$. Mustaqiem, S.H., M.Si. selaku dosen tetap pada bagian hukum pajak Fakultas Hukum Universitas Islam Indonesia, pada tanggal 11 Mei 2020
Menurut Maya, selaku account Representative Kantor Pelayanan Pajak Pratama Kota Yogyakarta, Jika wajib pajak yang telah memperoleh NPWP meninggal dunia dan meninggalkan warisan yang belum terbagi sebagaimana diatur dalam keputusan Direktorat Jenderal Pajak, maka warisan yang belum terbagi tersebut dalam kedudukannya sebagai subjek pajak menggunakan NPWP dari wajib pajak yang meninggal dunia dan ahli warisnya wajib melaporkan ke Kantor Pelayanan Pajak dengan mengisi formulir yang ditentukan. Sehingga, apabila tanah dan/bangunan yang menjadi warisan belum dilaporkan dalam SPT tahunan Pewaris maka atas permohonan SKB PPh pengalihan hak atas tanah dan/bangunan tersebut tidak dapat dikabulkan, namun SKB tersebut dapat diajukan kembali dan akan dikabulkan jika pajak terutang PPh tersebut sudah dilunasi. ${ }^{14}$

Dalam hal Pewaris semasa hidup sebagai wajib pajak yang tidak terdaftar/tidak memiliki NPWP sehingga Pewaris semasa hidup tidak pernah melaporkan hartanya dalam SPT tahunan, pihak KPP Kota Yogyakarta tetap mewajibkan ahli waris untuk mengajukan

${ }^{14}$ Hasil wawancara dengan Maya selaku account Representative Kantor Pelayanan Pajak Pratama Kota Yogyakarta, pada tanggal 29 Juli 2020 
permohonan SKB PPh atas warisan tersebut dan akan mengabulkan surat permohonan SKB yang diajukan oleh ahli waris. Dalam hal ini, KPP Kota Yogyakarta akan mengabulkan SKB PPh atas warisan yang diajukan oleh ahli waris dan ahli waris tidak dikenakan kewajiban untuk membayar pajak terutang walaupun pewaris tidak memiliki NPWP dan tidak pernah melaporkan hartanya dalam SPT tahunan. Hal tersebut dilakukan karena pihak KPP Kota Yogyakarta menganggap tidak ada pajak terutang yang harus dilunasi oleh ahli waris. 15

\section{Implementasi Penerbitan SKB PPh} Pengalihan Hak Atas tanah dan/bangunan atas Warisan Ditinjau dari Asas Kemudahan Administrasi

Kemudahan dalam administrasi menjadi prinsip yang sangat penting dalam sistem pemungutan pajak, dengan adanya sistem administrasi pajak yang baik, maka wajib pajak dapat memperoleh pelayanan yang optimal dan permasalahan yang dihadapi oleh wajib pajak dapat diselesaikan secara lebih cepat, sederhana dengan memberikan kepastian hukum yang terjamin. Sebagai syarat pendaftaran

15 Hasil wawancara dengan Maya selaku account Representative Kantor Pelayanan Pajak Pratama Kota Yogyakarta, pada tanggal 29 Juli 2020 pengalihan hak atas tanah dan/bangunan di kantor pertanahan kota Yogyakarta ahli waris diharuskan mengurus $\mathrm{SKB} \mathrm{PPh}$ pengalihan hak atas tanah dan/bangunan atas warisan terlebih dahulu di KPP Pratama Kota Yogyakarta. Dalam hal ini pelaksanaan penerbitan SKB PPh pengalihan hak atas tanah dan/bangunan atas warisan di Kota Yogyakarta dianggap belum memenuhi asas kemudahan administrasi.

Dalam konsep ease of administration, pemungutan pajak harus memperhatikan asas-asas yang mendasari suatu pemungutan pajak tersebut dilakukan. Ada empat indikator yang dapat digunakan untuk menilai suatu kebijakan Pemerintah dalam pemungutan dan/atau pembayaran pajak telah memenuhi prinsip ease of administration (kemudahan administrasi) yaitu certainty, efficiency, Convenience of Payment dan Simplicity, ${ }^{16}$ terkait dengan belum terpenuhinya asas kemudahan administrasi dalam penerbitan SKB $\mathrm{PPh}$ pengalihan hak atas tanah dan/bangunan karena warisan tersebut ditentukan berdasarkan indikator sebagai berikut:

\section{a) Certainty}

16 Haula Rosdiana dan edi slamet iriyanto,2013, Pengantar Ilmu Pajak:Kebijakan dan Implementasi di Indonesia, Rajawali Pers, Jakarta, hlm. 158 
Asas certainty menekankan pentingnya kepastian hukum dalam pemungutan pajak. Kepastian hukum adalah tujuan dari setiap Undang- Undang, sehingga dalam membuat undang- undang dan peraturan yang mengikat secara umum, maka harus diusahakan supaya ketentuan yang dimuat dalam undang- undang adalah jelas, tegas, dan tidak mengandung arti ganda atau memberikan peluang untuk ditafsirkan lain. Kepastian ini menjamin setiap orang untuk tidak ragu-ragu dalam menjalankan kewajiban dalam membayar pajak. ${ }^{17}$ Pada dasarnya, asas certainty berarti bahwa dalam ketentuan pemungutan pajak harus ada kepastian mengenai subjek pajak, objek pajak, dan tarif pajak serta bagaimana prosedur perpajakannya. ${ }^{18}$ Dalam penelitian ini, peneliti berpendapat bahwa aturan hukum terkait pajak atas warisan tersebut dinilai telah memenuhi unsur certainty/kepastian hukum. Hal tersebut dikarenakan aturan hukum terkait subjek pajak, objek pajak, dan prosedur perpajakan dalam pengalihan hak atas tanah dan/bangunan karena warisan telah diatur secara jelas, tegas, serta tidak mengandung arti ganda atau memberikan peluang untuk ditafsirkan lain.

\footnotetext{
${ }^{17}$ F.C. Susila Adiyanta, op.cit, hlm.31

${ }^{18}$ Mansury, R. 1996. Pajak Penghasilan Lanjutan, Ind-Hill-Co, Jakarta, hlm 18-25
}

Pertama, terkait subjek pajak penghasilan telah di atur secara tegas dalam Pasal 2 ayat (3) Undang-Undang Nomor 30 tahun 2008 tentang Pajak penghasilan menegaskan bahwa subjek pajak dalam negeri meliputi orang pribadi, warisan yang belum terbagi sebagai satu kesatuan, badan, dan bentuk usaha tetap. Sehingga, warisan yang belum terbagi adalah subjek pajak. Kedua, terkait objek pajak penghasilan telah di atur secara tegas dalam Pasal 4 ayat (1) dan ayat (2) Undang- Undang Pajak Penghasilan yang memberikan penegasan mengenai objek Pajak Penghasilan yaitu Penghasilan. Dalam Ketentuan terkait pengalihan hak atas tanah dan/bangunan karena warisan telah diatur dalam Pasal Pasal 4 ayat (3) Undang-undang Nomor 36 tahun 2008 tentang Pajak Penghasilan (UU $\mathrm{PPh}$ ) dan Pasal 6 huruf d Peraturan Pemerintah Nomor 34 Tahun 2016 tentang $\mathrm{PPh}$ atas Penghasilan dari Pengalihan Hak atas Tanah dan/atau Bangunan, dan Perjanjian Pengikatan Jual Beli atas Tanah dan/atau Bangunan beserta Perubahannya yang menyebutkan bahwa dikecualikan dari kewajiban pembayaran atau pemungutan Pajak Penghasilan atas penghasilan dari pengalihan harta berupa tanah dan/atau bangunan karena warisan, sehingga warisan 
termasuk penghasilan yang dikecualikan sebagai objek pajak.

Ketiga, terkait dengan prosedur perpajakan, agar ahli waris dikecualikan dari pemungutan biaya $\mathrm{PPh}$ atas penghasilan hak atas tanah dan/bangunan, maka berdasarkan Pasal 3 ayat (1) huruf a Peraturan Direktorat Jenderal Pajak Nomor 30/PJ/2009 tentang Tata Cara Pemberian Pengecualian dari Kewajiban Pembayaran atau Pemungutan Pajak Penghasilan atas Penghasilan dari Pengalihan Hak atas Tanah dan/atau Bangunan menyebutkan bahwa di dalam pengalihan hak atas tanah dan/bangunan karena warisan mensyaratkan bahwa harus disertai dengan adannya SKB (Surat Keterangan Bebas). Dalam surat edaran nomor SE-20/PJ/2015 memberikan persyaratan bahwa agar $\mathrm{PPh}$ atas warisan dikecualikan sebagai objek pajak dan agar ahli waris terbebas dari pemungutan $\mathrm{PPh}$ atas pengalihan hak atas tanah dan/bangunan karena warisan, maka ahli waris terlebih dahulu harus mengajukan permohonan SKB $\mathrm{PPh}$ ke KPP tempat Pewaris terdaftar/bertempat tinggal.

Dalam Pasal 5 ayat (1) dan ayat (2) Peraturan Direktur Jenderal Pajak nomor 30/PJ/2009 tentang tata Cara Pemberian Pengecualian dari Kewajiban Pembayaran atau Pemungutan Pajak penghasilan atas
Penghasilan dari Pengalihan Hak atas Tanah dan/bangunan menyatakan bahwa atas permohonan SKB PPh dari pengalihan hak atas tanah dan/bangunan karena warisan, kepala kantor pelayanan Pajak harus memberikan keputusan dalam jangka waktu paling lama 3 (tiga) hari kerja sejak tanggal surat permohonan SKB PPh diterima secara lengkap, kemudian, dalam Pasal 5 ayat (2) Peraturan Direktur Jenderal pajak tersebut menyatakan bahwa apabila dalam jangka waktu sebagaimana dimaksud pada ayat (1) kepala pelayanan pajak tidak memberikan keputusan, maka permohonan SKB tersebut dianggap dikabulkan dan kepala Kantor pelayanan pajak harus menerbitkan SKB $\mathrm{PPh}$ pengalihan hak atas tanah dan/bangunan karena warisan paling lama 2 (dua) hari kerja terhitung sejak berakhirnya jangka waktu SKB sebagaimana dimaksud pada ayat (1) berakhir.

Pada prinsipnya surat edaran tidak secara langsung mengikat secara hukum walaupun tetap mengandung relevansi hukum, namun kekuatan mengikatnya hanya bagi badan atau pejabat administrasi negara sendiri, meskipun ketentuan dalam peraturan kebijakan biasanya akan menyangkut 
masyarakat umum secara tidak langsung. ${ }^{19}$ Dari segi materi muatan, Surat Edaran seharusnya hanya menjelaskan atau membuat prosedur untuk mempermudah atau memperjelas peraturan yang mesti dilaksanakan. Oleh karena sifatnya hanya memperjelas, maka Surat Edaran tidak boleh bertentangan dengan undang- undang, peraturan pemerintah, atau peraturan yang secara heirarki lebih tinggi kedudukan hukumnya. ${ }^{92}$ kedudukan Surat Edaran tidak termasuk dalam kategori peraturan perundang-undangan melainkan sebagai instrumen administratif yang bersifat internal. Surat Edaran ditujukan untuk memberikan petunjuk lebih lanjut mengenai suatu norma peraturan perundang-undangan yang bersifat umum. Pada pelaksanaannya apabila terdapat Surat Edaran yang bertentangan atau tidak sesuai dengan peraturan perundang-undangan maka dapat dicabut sendiri oleh instansi yang mengeluarkan atau atas permintaan pihak yang berkepentingan. ${ }^{20}$

b) Efficiency

Asas ini berkaitan dengan biaya pemungutan pajak yang menjelaskan bahwa biaya pemungutan pajak sejak wajib pajak

19 Bagir Manan dan Kuntana Magnar,1997, Beberapa Masalah Hukum Tata Negara Indonesia, PT Alumni, Bandung, hlm 170.

${ }^{20}$ Ardie Suryo, op. Cit, hlm 85 membayar pajak sampai uang pajak masuk ke kas negara hendaknya seminim mungkin. ${ }^{21}$ Dengan kata lain, pemungutan pajak dikatakan efisien jika cost of taxation/administrative costs atau beban administratifnya rendah. Komponen cost of taxation/ administrative costs adalah biayabiaya atau beban-beban yang dapat diukur dengan nilai uang (tangible) maupun yang tidak dapat diukur dengan uang (intangible) yang harus dikeluarkan/ditanggung oleh wajib pajak berkaitan dengan proses pelaksanaan kewajiban-kewajiban dan hakhak perpajakan. ${ }^{22}$

Cedric Sandford menyatakan bahwa komponen cost of taxation, antara lain yaitu Fiscal Cost yaitu biaya atau beban yang dapat diukur dengan nilai uang yang harus dikeluarkan/ditanggung oleh wajib pajak berkaitan dengan proses pelaksanaan kewajiban-kewajiban dan hak-hak perpajakan, Time Cost adalah biaya berupa waktu yang dibutuhkan untuk melaksanakan kewajiban-kewajiban dan hak-hak perpajakan dan Psychological costs adalah biaya psikis/psikologis antara lain berupa stress dan/atau ketidaktenangan, kegamangan. kegelisahan, yang terjadi dalam proses pelaksanaan kewajiban-

\footnotetext{
${ }^{21}$ Marihot Pahala Siahaan, op.cit., hlm. 57.

${ }^{22}$ Haula rosidana, Op.cit, hlm.177
} 
kewajiban dan hak-hak perpajakan, ${ }^{23}$ Selain itu, menurut Kamus Besar Bahasa Indonesia (KBBI), efisiensi adalah ketepatan cara (usaha/kerja) dalam melaksanakan sesuatu (dengan tidak membuang-buang waktu, tenaga, dan biaya). ${ }^{24}$

Berkaitan dengan Pengalihan hak atas tanah dan/bangunan karena warisan, dalam penelitian ini peneliti berpendapat bahwa Kantor Pelayanan Pajak Pratama Kota Yogyakarta belum memenuhi asas efficiency perpajakan. Hal tersebut dikarenakan cost of taxation/administrative costs relatif tinggi yang berpengaruh pada tingkat efisiensi penerbitan SKB PPh tersebut. Pemungutan pajak dikatakan efisien jika cost of taxation/administrative costs atau beban administratifnya rendah. Namun, dalam penerbitan SKB PPh atas warisan tersebut cost of taxation/administrative costs yang ditanggung oleh ahli waris tinggi. Hal tersebut dapat dilihat dari komponen administrative costs yaitu time cost dan Psychological costs yang dirasakan oleh ahli waris. Dilihat dari segi time cost, keputusan penerbitan SKB PPh Pengalihan hak atas tanah dan/bangunan karena warisan oleh KPP Pratama Kota Yogyakarta pada prakteknya membutuhkan waktu lebih dari 3

\footnotetext{
${ }^{23}$ Ibid.,

${ }^{24}$ https://kbbi.kemdikbud.go.id/ di akses pada tanggal 10 oktober 2020 pukul 14.15 WIB
}

(tiga) hari, bahkan mencapai 1 (satu) bulan. Dengan lamanya penerbitan SKB $\mathrm{PPh}$ pengalihan hak atas tanah dan/bangunan karena warisan tersebut, ahli waris merasa waktu yang dimilikinya terbuang hanya untuk menunggu lamanya penerbitan SKB PPh oleh pihak KPP Kota Yogyakarta yang tidak sesuai dengan Direktorat Jenderal Pajak Nomor 30/PJ/2009, padahal waktu yang dimiliki oleh ahli waris merupakan sumber daya terbatas yang seharusnya dapat digunakan semaksimal mungkin. kemudian dlihat dari segi Psychological costs, dengan lamanya penerbitan SKB PPh tersebut, ahli waris dan PPAT selaku pihak yang membantu ahli waris dalam mengajukan permohonan SKB tersebut merasakan adannya kegelisahan dan ketidaktenangan terutama bagi ahli waris yang ingin segera mendaftarakan tanah dan/bangunan atas warisan tersebut namun terhambat akibat lamanya keputusan penerbitan $\mathrm{SKB} \mathrm{PPh}$ pengalihan hak atas tanah dan/bangunan karena warisan.

c) Convienience of Payment

Convenience of Payment Pajak memberikan arti bahwa pajak harus dipungut pada saat yang tepat (Pay as You Earn). Pemungutan pajak harus memperhatikan kondisi wajib pajak pada saat yang nyaman. Asas ini menyatakan 
bahwa saat pembayaran pajak hendaklah dimungkinkan pada saat yang menyenangkan/ memudahkan wajib pajak. ${ }^{25}$

Berkaitan dengan Pengalihan hak atas tanah dan/bangunan karena warisan, dalam penelitian ini peneliti berpendapat bahwa Kantor Pelayanan Pajak Pratama Kota Yogyakarta belum memenuhi asas Convenience of Payment perpajakan. Dalam asas Convenience of Payment tersebut menghendaki bahwa dalam pemungutan pajak harus memperhatikan kondisi wajib pajak yang nyaman, namun dengan lamanya proses penerbitan SKB PPh pengalihan hak atas tanah dan/bangunan justru memberikan ketidaknyamanan yang menimbulkan kerugian bahkan penderitaan bagi ahli waris.

Menurut Mustofa, kerugian yang dapat dirasakan ahli waris adalah tidak dapat dilakukannya jual beli tanah warisan dengan segera. apabila ahli waris mendapatkan tanah dan/bangunan karena warisan, maka para ahli waris memilih sepakat untuk menjual tanah warisan. Hal tersebut dilakukan karena pembagian warisan dengan uang tunai dirasa lebih adil daripada pembagian warisan yang dilakukan dengan membagi tanah dan/bangunan warisan tersebut. Namun, dengan penerbitan SKB $\mathrm{PPh}$ atas waris yang lama maka dapat

\footnotetext{
${ }^{25}$ Rosdiana,H \& Irianto,E.S, Op.Cit.,
}

menghambat proses jual beli tanah warisan yang akan dilaksanakan oleh ahli waris dan pihak ketiga, sehingga hal tersebut merugikan ahli waris yang ingin segera menjual tanah warisannya, bahkan dengan lamanya penerbitan SKB PPh tersebut menjadikan jual beli yang akan dilaksanakan menjadi batal dikarenakan pihak pembeli tidak dapat menunggu terlalu lama. ${ }^{26}$ Kerugian lainnya juga disampaikan oleh Bimo Sanjaya selaku Notaris Yogyakarta ahli waris dapat kehilangan kesempatan untuk mengembangkan usahanya, apabila ahli waris telah mendapatkan bagian warisan yang seharusnya didapat dan ingin menjaminkan tanah dan/bangunan tersebut kepada pihak Bank, maka hal tersebut tidak dapat dilakukan dikarenakan tanah warisan yang akan menjadi jaminan belum atas nama ahli waris dan masih atas nama Pewaris. Atas hal tersebut, ahli waris merasa kehilangan kesempatannya untuk mengembangkan usahanya secara maksimal dikarenakan penerbitan SKB yang terlalu lama sehingga menyebabkan ketidaknyamanan yang menimbulkan kerugian bagi ahli waris. ${ }^{27}$

${ }^{26}$ Hasil wawancara dengan Mustofa S.H., Notaris dan PPAT di Kota Yogyakarta, pada tanggal 10 September 2020

27 Hasil wawancara dengan Bimo Seno Sanjaya, S.H, Notaris dan PPAT di Kota Yogyakarta, pada tanggal 08 September 2020. 


\section{d) Simplicity}

Menurut Mustaqiem, prinsip-prinsip pelayananan publik yang baik yang harus diterapkan oleh pelayan publik, yaitu: ${ }^{28}$

1) Kesederhanaan; Kejelasan dan kepastian dalam hal prosedur, tata cara pelayanan dan persyaratan pelayanan;

2) Keamanan proses dan produk dalam pelayanan publik;

3) Keterbukaan dalam pelayanan publik;

4) Effisiensi, ekonomis, keadilan dan ketepatan waktu.

Asas sederhana yang dimaksud adalah prosedur perpajakan harus cepat, lancar, tepat, mudah dipahami dan mudah dilaksanakan oleh masyarakat yang meminta pelayanan. ${ }^{29}$ Dengan demikian, wajib pajak tidak akan mengalami kesulitan dalam pembayaran pajak baik dari segi perhitungan maupun dari segi waktu. Berkaitan dengan pengalihan hak atas tanah dan/bangunan karena warisan, dalam penelitian ini peneliti berpendapat bahwa Kantor Pelayanan Pajak Pratama Kota Yogyakarta belum memenuhi asas simplicity atau asas sederhana perpajakan. Dilihat dari segi waktu,

28 Hasil wawancara dengan Dr. H. Mustaqiem, S.H., M.Si. selaku dosen tetap pada bagian hukum pajak Fakultas Hukum Universitas Islam Indonesia, pada tanggal 11 Mei 2020

29 Hasil wawancara dengan Dr. $H$. Mustaqiem, S.H., M.Si. selaku dosen tetap pada bagian hukum pajak Fakultas Hukum Universitas Islam Indonesia, pada tanggal 11 Mei 2020 walaupun jangka waktu penerbitan SKB PPh atas warisan telah diatur dalam Pasal 5 ayat (1) dan ayat (2) Peraturan Direktur Jenderal Pajak nomor 30/PJ/2009, namun pada prakteknya pihak KPP Kota Yogyakarta membutuhkan waktu melebihi dari jangka waktu yang telah ditentukan Peraturan Direktur Jenderal pajak tersebut. Menurut Mustaqiem, apabila dalam penerbitan SKB $\mathrm{PPh}$ pengalihan hak atas tanah dan/bangunan karena warisan tersebut melebihi jangka waktu yang telah ditentukan dalam Peraturan Direktorat Jenderal Pajak Nomor 30/PJ/2009, maka hal tersebut tidak sesuai dengan prinsip ketepatan waktu dan kesederhanaan yang mengharuskan bahwa prosedur perpajakan harus cepat, lancar dan tepat sehingga tidak menyulitkan masyarakat dalam hal ini ahli waris yang mengajukan permohonan SKB PPh pengalihan hak atas tanah dan/bangunan karena warisan. ${ }^{30}$

\section{Penutup}

\section{Kesimpulan}

Berdasarkan hasil penelitian serta pembahasan yang telah dilakukan, maka terdapat kesimpulan yaitu:

30 Hasil wawancara dengan Dr. H. Mustaqiem, S.H., M.Si. selaku dosen tetap pada bagian hukum pajak Fakultas Hukum Universitas Islam Indonesia, pada tanggal 11 Mei 2020 
Implementasi Penerbitan SKB PPh Pengalihan hak atas tanah dan/bangunan karena warisan di Kantor Pelayanan Pajak Pratama Kota Yogyakarta belum sesuai dengan asas ease of administration atau asas kemudahan administrasi. Hal tersebut dikarenakan belum terpenuhinya empat indikator kemudahan administrasi yaitu certainty, efficiency, Convenience of Payment, dan simplicity secara kumulatif sebagai tolak ukur terpenuhinya kemudahan administrasi perpajakan. Dalam pengalihan hak atas tanah dan/bangunan karena warisan hanya terpenuhi satu indikator yaitu Certainty, sedangkan ketiga indikator yang lain yaitu efficiency, Convenience of Payment, dan simplicity belum terpenuhi.

\section{DAFTAR PUSTAKA}

\section{Buku}

Bambang Sunggono,2006, Metodologi

Penelitian, Raja Grafindo

Manan Bagir dan Kuntana Magnar,1997, Beberapa Masalah Hukum Tata Negara Indonesia, PT Alumni, Bandung Mansury.1994, Panduan Konsep Utama Pajak Penghasilan Indonesia, Bina Rena Pariwara, Jakarta

Mertokusumo Sudikno, 1988, Hukum dan Politik Agraria, Karunika Univeristas Terbuka, Jakarta
Rosdiana, Haula \& Irianto, E.S, 2012, Pengantar Ilmu Pajak, PT Raja Grafindo, Jakarta

Siahaan Marihot P,2004, Utang Pajak, Pemenuhan Kewajiban dan Penagihan Pajak dengan Surat Paksa, PT RajaGrafindo Persada, Jakarta

Sumardjono, Maria SW,2014, Metodologi Penelitian Hukum, Universitas Gadjah Mada, Yogyakarta

Suparnyo, 2012, Hukum Pajak Suatu

Sketsa Asas, Pustaka Magister, Semarang

Suandy Erly,2008, Hukum Pajak, Edisi Keempat, Salemba Empat, Yogyakarta Peraturan perundang-undangan

Undang-Undang Nomor 5 Tahun 1960 tentang Peraturan Dasar Pokok-Pokok Agraria. Lembaran Negara Republik Indonesia Tahun 1960 Nomor 104 dan Tambahan Lembaran Negara Republik Indonesia Nomor 2043

Undang-Undang Nomor 20 tahun 2000 tentang Perubahan atas UndangUndang Nomor 21 Tahun 1997 tentang Bea Perolehan Hak atas Tanah dan/Bangunan Lembaran Negara Republik Indonesia Tahun 2000 Nomor 130 dan Tambahan Lembaran Negara Republik Indonesia Nomor 3988

Undang-Undang Nomor 28 Tahun 2007 tentang Perubahan Ketiga atas 
Undang-Undang Nomor 6 Tahun 1983 tentang Ketentuan Umum dan Tata cara Perpajakan Lembaran Negara Republik Indonesia tahun 2007 Nomor 85 dan Tambahan Lembaran Negara Republik Indonesia Nomor 4740

Undang-Undang Nomor 36 Tahun 2008 tentang Perubahan Keempat atas Undang- Undang Nomor 7 Tahun 1983 tentang Pajak Penghasilan. Lembaran Negara Republik Indonesia Tahun 2008 Nomor 133 dan Tambahan Lembaran Negara Republik Indonesia Nomor 4893. Peraturan Direktur Jenderal Pajak Nomor PER-30/PJ/2009 tentang Tata Cara Pemberian Pengecualian dari Kewajiban Pembayaran atau Pemungutan Pajak Penghasilan dari Pengalihan Hak atas tanah dan/atau Bangunan
Surat Edaran Direktur Jenderal Pajak (SE Dirjen Pajak) Nomor 20/PJ/2015 tentang pemberian Surat Keterangan Bebas pajak penghasilan dari pengalihan hak atas tanah dan/atau bangunan karena warisan

\section{Tesis}

Kesumo Muhamad Ardie Suryo, "Analisis Yuridis Mengenai Kewajiban Ahli Waris Dalam Pemenuhan Surat Keterangan Bebas Pajak Penghasilan (SKB PPh) Pada Pewarisan Hak Atas Tanah dan Bangunan di Kantor Pertanahan Kota Yogyakarta", Tesis, Program Studi Magister KenotariatanFakultas Universitas Gadjah Mada Yogyakarta, 2018.

\section{Internet}

https://kbbi.kemdikbud.go.id/ di akses pada tanggal 10 oktober 2020 pukul 14.15 WIB 